\title{
GAMBARAN KELELAHAN KERJA SUBJEKTIF PADA OPERATOR MESIN PRODUKSI PAKAN IKAN
}

\section{THE DESCRIPTION OF WORK FATIGUE ON FISH FEED PRODUCTION MACHINE OPERATOR}

\author{
Tria Melissa, Endang Dwiyanti \\ Departemen Keselamatan dan Kesehatan Kerja \\ Fakultas Kesehatan Masyarakat Universitas Airlangga \\ E-mail: triamelissa@rocketmail.com
}

\begin{abstract}
Fatigue is a subjective feeling that everyone feels. Work fatigue may occur due to various factors such as age, years of working life, nutritional status, and noise. The purpose of this study was to know the relation between the factors cause work fatigue at fish feed production machine operator. This research was descriptive observational with cross-sectional design. Population in this research is all worker machine operator of fish feed production who worked in the same shift at the time of the research. Samples were taken with a total sampling principle that all operator's workers from production area who totaled 24 people. The variables were age, years of working life, nutritional status, noise, and subjective work fatigue. The results showed that most of the respondents were over 40 years old, had a working period over 10 years, had normal nutritional status, worked in the work area exceeding the noise treshold limit value and had moderate fatigue. The conclusions of this study are age, years of working life, and nutritional status has no relationship causing fatigue. Noise can be one of the factor of the occurrence of work fatigue because (54.2\%) workers who work in the work area exceeding the standardize had a moderate fatigue.
\end{abstract}

Keywords: noise, nutritional status, worker, work fatigue

\begin{abstract}
ABSTRAK
Kelelahan merupakan perasaan subjektif yang dirasakan setiap orang. Kelelahan kerja dapat terjadi karena berbagai faktor seperti umur, masa kerja, status gizi, dan kebisingan. Penelitian ini dilakukan untuk melihat gambaran kelelahan kerja subjektif pada pekerja operator mesin produksi pakan ikan. Penelitian ini dilakukan di salah satu perusahaan yang memproduksi produk di bidang akuakultur, salah satunya adalah pakan ikan. Penelitian ini adalah penelitian observasional deskriptif dengan desain cross-sectional. Populasi dalam penelitian ini adalah seluruh pekerja operator mesin area produksi yang bekerja dalam satu shift yang sama pada saat penelitian berlangsung. Sampel dalam penelitian ini merupakan total populasi sebesar 24 orang pekerja operator mesin produksi. Variabel yang diteliti dalam penelitian yaitu umur, masa kerja, status gizi, kebisingan, dan kelelahan kerja subjektif. Hasil penelitian didapatkan sebagian besar responden berumur di atas 40 tahun, memiliki masa kerja di atas 10 tahun, memiliki status gizi normal, bekerja di area kerja melebihi Nilai Ambang Batas (NAB) kebisingan dan memiliki tingkat kelelahan sedang. Kesimpulan dari penelitian ini adalah umur, masa kerja, dan status gizi tidak mempunyai hubungan yang menyebabkan terjadinya kelelahan kerja. Kebisingan dapat menjadi salah satu faktor terjadinya kelelahan kerja karena $(54,2 \%)$ pekerja yang berada di area kerja yang memiliki kebisingan di atas NAB memiliki kelelahan sedang.
\end{abstract}

Kata kunci: kebisingan, kelelahan kerja, pekerja, status gizi

\section{PENDAHULUAN}

Bekerja merupakan kegiatan yang dilakukan setiap orang untuk memenuhi kehidupan sehari-hari. Seseorang rela melakukan berbagai pekerjaan setiap harinya tanpa mengenal rasa lelah meskipun tanda-tanda kelelahan sudah muncul pada tubuh pekerja. Keadaan lelah dapat terjadi karena tubuh mempunyai batasan dalam melakukan aktivitas.
Industri merupakan salah satu tempat yang membutuhkan banyak pekerja, tidak heran banyak masyarakat yang bekerja di bidang industri.

Data yang diambil dari website Badan Penyelenggara Jaminan Sosial (BPJS) Ketenagakerjaan akhir tahun 2015 menyatakan telah terjadi kecelakaan kerja sebanyak 105.182 kasus dan tercatat 2.375 orang korban meninggal 
dunia. Salah satu yang menyebabkan hal ini terjadi adalah pelaksanaan dan pengawasan Keselamatan dan Kesehatan Kerja (K3) yang belum maksimal, sekaligus perilaku masyarakat yang belum optimal. Hasil penelitian yang dilakukan oleh Kementerian Jepang yang melibatkan 16.000 pekerja dari 12.000 perusahaan di negara tersebut didapatkan sebesar $65 \%$ pekerja mengeluhkan kelelahan akibat kerja rutin, 28\% mengeluhkan kelelahan mental dan kurang lebih 7\% pekerja mengeluh mengalami stres berat (Eraliesa, 2008).

Kelelahan bersifat subjektif bagi setiap orang dikarenakan sering dikaitkan dengan perasaan. Selain dipengaruhi faktor fisik dan faktor biologis, kelelahan dapat dipengaruhi oleh faktor psikologi (psikis). Hal ini yang menyebabkan kelelahan menjadi suatu masalah kesehatan kerja yang perlu mendapat perhatian khusus.

Budiono (2003), menyatakan kelelahan kerja dapat dilihat dari melemahnya tenaga dalam melakukan kegiatan atau pekerjaan, sehingga akan meningkatkan tingkat kesalahan dalam melaksanakan pekerjaan dan berakibat fatal yaitu dapat terjadi kecelakaan kerja. Risiko yang dapat ditimbulkan dari terjadinya kelelahan menurut Triyunita dkk, (2013) diantaranya adalah menurunnya motivasi kerja, terjadi banyak kesalahan dalam bekerja, produktivitas kerja rendah, rendahnya performansi, rendahnya kualitas kerja, stres kerja, timbulnya penyakit akibat kerja, cidera, dan terjadi kecelakaan kerja. Menurut Setyawati (2010), lebih dari 60\% kejadian kecelakaan kerja mendapat kontribusi dari pekerja yang mengalami kelelahan. Kelelahan kerja telah terbukti memberikan salah satu penyebab utama dalam kecelakaan kerja adalah kelelahan (fatigue).

Faktor yang menyebabkan terjadinya kelelahan di industri menurut Setyawati (2010) sangat beranekaragam diantaranya dipengaruhi oleh kondisi kesehatan, lingkungan kerja, dan juga beban kerja. Kelelahan dapat pula dipengaruhi oleh faktor internal seperti umur, jenis kelamin, status gizi, status kesehatan, pola makan dan keadaan psikologi.

Kelelahan kerja yang tidak ditangani secara cepat dan segera beristirahat, akan menyebabkan kelelahan itu terakumulasi dalam sehari, sehingga dapat berdampak memperparah kondisi kesehatan. Menurut Tarwaka (2010), menyatakan bahwa risiko yang ditimbulkan dari kelelahan kerja diantaranya menurunnya motivasi kerja, performansi rendah, terjadi banyak kesalahan, produktivitas kerja rendah, stres kerja, rendahnya kualitas kerja, penyakit akibat kerja, cedera dan terjadi kecelakaan kerja. Menurut Setyawati (2010) menyatakan bahwa dampak dari kelelahan kerja adalah badan terasa tidak nyaman, prestasi kerja menurun, menurunnya semangat kerja, dan menurunkan produktivitas kerja.

Hasil penelitian dari Purwindasari (2013) di PT. Charoen Pokphand Indonesia Krian pada pekerja bagian packing menunjukkan dari 33 tenaga kerja sebagian besar mengalami tingkat kelelahan ringan sebesar 42,4\%, kelelahan sedang sebesar 30,3\% dan kelelahan tinggi sebesar 27,3\%. Kelelahan tersebut mempunyai hubungan sedang dengan tingkat pendidikan, status gizi, lama waktu tidur, dan iklim kerja.

Penggunaan peralatan atau teknologi yang semakin modern dapat memberikan dampak positif yaitu membantu tenaga kerja dalam menyelesaikan pekerjaannya. Hal itu juga dapat menimbulkan pengaruh negatif jika peralatan atau teknologi tersebut tidak dikelola dengan baik. Penggunaan mesin dapat menjadi sumber bising di tempat kerja. Kebisingan yang berlangsung setiap hari terus-menerus, suatu saat akan berdampak buruk yang akan menyebabkan gangguan pendengaran (Sasongko, 2000). Kebisingan merupakan salah satu faktor lingkungan fisik yang berpotensi menimbulkan bahaya yang dapat menimbulkan gangguan kesehatan terhadap pekerja. Hasil penelitian yang dilakukan oleh Hayati (2012) tentang hubungan tingkat kebisingan dengan kelelahan kerja pada pekerja di bagian ring frame PT. Kusumaputra Santosa Karanganyar menunjukkan bahwa terdapat hubungan yang signifikan antara intensitas kebisingan dengan kelelahan kerja dengan hasil $\mathrm{p}=0,017$ artinya $\mathrm{p} \leq 0,05$ yang berarti semakin tinggi intensitas kebisingan maka kelelahan kerja semakin meningkat. Berdasarkan hasil penelitian lain yang dilakukan Irwan Harwanto (2004) di Depo Lokomotif PT Kereta Api Daerah Operasi IV Semarang menyatakan terdapat $69,6 \%$ pekerja mengalami kelelahan ringan, dan masing-masing $13 \%$ dan $17,4 \%$ mengalami kelelahan ringan dan berat karena terkena paparan bising melebihi nilai ambang batas yaitu sekitar 85,8-90,6 dBA.

Kelelahan kerja juga disebabkan oleh faktor internal. Salah satu faktor internal yang menyebabkan kelelahan kerja adalah status gizi. Tarwaka, dkk (2004) menyatakan bahwa status gizi dapat menjadi penyebab kelelahan kerja dimana hal ini didukung oleh hasil penelitian Oentoro (2004) yang menunjukkan orang yang berada dalam kondisi 
gizi yang kurang baik dalam arti intake makanan dalam tubuh kurang dari normal maka akan lebih mudah mengalami kelelahan dalam melakukan pekerjaan. Hal ini menyatakan bahwa seseorang memiliki hubungan antara status gizinya dengan performa tubuh secara keseluruhan. Suma'mur (2009) dan teori kombinasi pengaruh penyebab kelelahan dan penyegaran oleh Grandejan (2004) juga mengatakan bahwa salah satu faktor yang memengaruhi kelelahan pada pekerja adalah status gizi, karena status gizi berkaitan dengan daya kerja serta kesehatan pekerja. Status gizi merupakan keadaan tubuh sebagai akibat dari konsumsi makanan dan zat-zat gizi.

Hasil penelitian Tasmi (2015) menyatakan bahwa terdapat hubungan antara status gizi dan kelelahan kerja pada pekerja di PTPN I PKS Pulau Tiga tahun 2015. Hasil penelitian Herliani (2012) yang dilakukan di daerah Wirun Sukoharjo pada pekerja industri pembuatan gamelan juga menyatakan bahwa status gizi memengaruhi kelelahan kerja sebesar 11,2\%.

PT. XYZ merupakan perusahaan yang memproduksi pakan ikan dengan proses produksinya menggunakan mesin yang canggih. Penggunaan mesin dapat menyebabkan timbulnya suara yang dihasilkan dari mesin tersebut. Walaupun dalam produksinya sudah menggunakan mesin, namun tidak dapat dipungkiri bahwa tenaga manusia masih dibutuhkan dalam proses produksi. Tenaga manusia diperlukan sebagai operator mesin tersebut, untuk menjaga agar proses pengolahan pakan yang menggunakan mesin dapat berjalan dengan lancar. Pekerja yang bekerja sebagai operator tersebut selama melaksanakan pekerjaan akan terpapar suara bising yang dihasilkan dari masing-masing mesin. Hal itulah yang dapat menyebabkan pekerja operator tersebut mengalami kelelahan akibat paparan bising terus menerus yang dihasilkan oleh mesin yang menyala. Kelelahan kerja dapat mengakibatkan kecelakaan yang dapat menyebabkan kerugian bukan hanya bagi tempat kerja namun juga dari segi waktu, biaya, maupun produktivitas pekerja (Suma'mur, 2009).

Penelitian ini bertujuan untuk melihat gambaran kelelahan kerja subjektif yang terjadi pada pekerja operator area produksi PT. XYZ Sidoaarjo. Kelelahan kerja dalam penelitian merupakan kelelahan yang diukur secara subjektif mengenai keluhan perasaan kelelahan yang dialami pekerja.

\section{METODE}

Penelitian ini merupakan penelitian observasional karena data diperoleh melalui pengamatan tanpa memberi perlakuan pada objek. Berdasarkan sistem analisisnya, penelitian ini bersifat deskriptif yaitu metode untuk membuat gambaran tentang suatu keadaan secara objektif. Ditinjau dari waktu penelitian, penelitian ini bersifat cross-sectional karena pengamatan terhadap variabel dilakukan pada periode waktu yang sama.

Penelitian dilakukan di PT. XYZ yang berada di Sepanjang, Sidoarjo. Penelitian berlangsung dari Februari-Juni 2017. Populasi dalam penelitian ini adalah seluruh pekerja yang bekerja sebagai operator area produksi PT. XYZ Sidoarjo sebanyak 24 orang. Sampel dalam penelitian ini adalah seluruh populasi pekerja operator area produksi PT. XYZ Sidoarjo dengan kriteria inklusi bekerja pada satu shift kerja yang sama yang berjumlah 24 orang.

Variabel dalam penelitian ini meliputi umur, masa kerja, status gizi, kebisingan, dan kelelahan subjektif. Sumber data yang digunakan adalah data primer dan data sekunder. Data primer didapatkan dengan menggunakan kuesioner dan pengukuran langsung. Data sekunder yang diperoleh antara lain mengenai gambaran umum dan dokumen umum mengenai PT. XYZ Sidoarjo.

Instrumen pengumpulan data yang digunakan mengacu pada teknik pengumpulan data yang dilakukan. Instrumen yang digunakan antara lain kuesioner untuk mengetahui karakteristik individu seperti umur dan masa kerja responden. Kuesioner yang digunakan untuk mengukur kelelahan kerja menggunakan kuesioner International Fatigue Research Committee (IFRC) yang berisi 30 pertanyaan dengan rincian 10 pertanyaan tentang pelemahan kegiatan, 10 pertanyaan tentang pelemahan motivasi serta 10 pertanyaan tentang gambaran kelelahan fisik. Untuk mengukur status gizi menggunakan microtoise dan timbangan berat badan. Sound level meter digunakan untuk mengukur tingkat kebisingan di area kerja operator produksi PT. XYZ Sidoarjo. Hasil pengukuran dicatat di lembar pengukuran untuk status gizi dan kebisingan.

Data yang diperoleh dilakukan scoring untuk mengetahui tingkat kelelahan, lalu dikategorikan menjadi kelelahan rendah, sedang, tinggi, dan sangat tinggi. Data hasil pengukuran kebisingan 
dikategorikan menjadi 2 (dua), yaitu sesuai NAB dan melebihi NAB. Untuk hasil pengukuran status gizi, data yang didapat dikategorikan menjadi kurang, normal, dan lebih. Semua data yang diperoleh kemudian dianalisis dengan tabel dan narasi. Data antar variabel dianalisis secara deskriptif.

\section{HASIL}

\section{Karakteristik Responden}

Karakteristik responden dalam penelitian ini meliputi umur pada Tabel 1 dan masa kerja yang dikelompokkan pada Tabel 2. Hasil pada Tabel 1 dapat diketahui bahwa frekuensi umur responden terbanyak berada pada kategori umur di atas 40 tahun sebesar $50 \%$.

Tabel 1. Distribusi Umur Responden di PT. XYZ Tahun 2017

\begin{tabular}{ccc}
\hline Umur (tahun) & Frekuensi & Persentase (\%) \\
\hline $18-30$ & 6 & 25 \\
$31-40$ & 6 & 25 \\
$>40$ & 12 & 50 \\
\hline
\end{tabular}

Tabel 2 merupakan distribusi frekuensi masa kerja pada responden penelitian. Hasil dalam Tabel 2 menunjukkan bahwa sebagian besar responden memiliki masa kerja di atas 10 tahun sebesar $66,7 \%$.

Tabel 2. Distribusi Masa Kerja Responden di PT. XYZ Tahun 2017

\begin{tabular}{ccc}
\hline Masa Kerja (tahun) & Frekuensi & Persentase (\%) \\
\hline$\leq 5$ & 6 & 25,0 \\
$6-10$ & 2 & 8,3 \\
$>10$ & 16 & 66,7 \\
\hline
\end{tabular}

\section{Status Gizi}

Status gizi diperoleh dengan cara menghitung Indeks Massa Tubuh (IMT). Pengukuran IMT dilakukan dengan mengukur tinggi badan dan berat badan responden dengan menggunakan meteran tinggi badan dan timbangan berat badan. Hasil pengukuran dan perhitungan yang telah dilakukan dibagi menjadi 3 kategori, yaitu status gizi kurang, status gizi normal, dan status gizi lebih.
Tabel 3. Distribusi Statu Gizi Responden di PT. XYZ Tahun 2017

\begin{tabular}{lcc}
\hline \multicolumn{1}{c}{ Status Gizi } & Frekuensi & Persentase (\%) \\
\hline Kurang & 1 & 4,2 \\
Normal & 13 & 54,2 \\
Lebih & 10 & 41,7 \\
\hline
\end{tabular}

Hasil pengukuran dan perhitungan status gizi dapat dilihat pada Tabel 3. Hasil pada Tabel 3 dapat diketahui bahwa sebagian besar responden memiliki status gizi normal sebanyak 12 responden atau $54,2 \%$. Responden dengan status gizi kurang sebesar $4,2 \%$ dan responden dengan status gizi lebih dalam penelitian sebesar $41,7 \%$.

\section{Kebisingan}

Pengukuran kebisingan dilakukan di area produksi pakan ikan PT. XYZ Sidoarjo. Pengukuran dilakukan di tempat pekerja operator berada selama bekerja dengan menggunakan alat sound level meter dengan hasil pada Tabel 4. Hasil pengukuran pada Tabel 4 dapat diketahui bahwa sebanyak 7 responden atau sebesar $29,2 \%$ pekerja operator area produksi pakan ikan berada di area kerja yang intensitas kebisingannya sudah sesuai NAB, dan sebanyak 17 responden atau sebesar $70,8 \%$ bekerja di kondisi lingkungan kerja dengan intensitas kebisingan melebihi NAB.

\section{Kelelahan Kerja Subjektif}

Hasil pengukuran kelelahan kerja subjektif pada responden penelitian dikelompokkan pada Tabel 5.

Tabel 4. Kebisingan Area Produksi Pakan Ikan di PT. XYZ Tahun 2017

\begin{tabular}{lcc}
\hline \multicolumn{1}{c}{ Kebisingan } & Frekuensi & Persentase (\%) \\
\hline Sesuai NAB & 7 & 29,2 \\
Melebihi NAB & 17 & 70,8 \\
\hline
\end{tabular}

Tabel 5. Distribusi Tingkat Kelelahan Subjektif Operator Mesin Produksi Pakan Ikan di PT. XYZ Tahun 2017

\begin{tabular}{lcc}
\hline \multicolumn{1}{c}{ Kelelahan } & Frekuensi & Persentase (\%) \\
\hline Rendah & 3 & 12,5 \\
Sedang & 16 & 66,7 \\
Tinggi & 5 & 20,8 \\
\hline
\end{tabular}


Hasil pada Tabel 5 menunjukkan bahwa kelelahan yang dirasakan oleh responden penelitian, sebesar $12,5 \%$ pekerja memiliki kelelahan rendah, $66,7 \%$ pekerja memiliki kelelahan sedang, dan 20,8\% pekerja memiliki kelelahan dalam tingkatan tinggi. Tidak ditemukan responden dalam penelitian yang memiliki tingkat kelelahan sangat tinggi.

\section{Tabulasi Silang Umur dan Kelelahan Kerja Subjektif}

Hasil pada Tabel 6 menunjukkan bahwa mayoritas umur responden yang mengalami kelelahan rendah yaitu umur lebih dari 40 tahun $8,3 \%$. Mayoritas umur responden yang mengalami kelelahan sedang dan tinggi yaitu umur lebih dari 40 tahun masing-masing sebesar $29,2 \%$ dan $12,5 \%$.

Tabel 6. Tabulasi Silang Umur dan Kelelahan Kerja Subjektif di PT. XYZ Tahun 2017

\begin{tabular}{ccccccr}
\hline \multirow{2}{*}{$\begin{array}{c}\text { Umur } \\
\text { (tahun) }\end{array}$} & \multicolumn{6}{c}{ Kelelahan } \\
\cline { 2 - 7 } & \multicolumn{2}{c}{ Rendah } & \multicolumn{2}{c}{ Sedang } & \multicolumn{2}{c}{ Tinggi } \\
\cline { 2 - 7 } & $\mathbf{n}$ & $\mathbf{( \% )}$ & $\mathbf{n}$ & $\mathbf{( \% )}$ & $\mathbf{n}$ & $\mathbf{( \% )}$ \\
\hline $18-30$ & 0 & 0 & 5 & 20,8 & 1 & 4,2 \\
$31-40$ & 1 & 4,2 & 4 & 16,7 & 1 & 4,2 \\
$>40$ & 2 & 8,3 & 7 & 29,2 & 3 & 12,5 \\
\hline
\end{tabular}

Tabel 7. Tabulasi Silang Masa Kerja dan Kelelahan Kerja Subjektif di PT. XYZ Tahun 2017

\begin{tabular}{ccccccc}
\hline \multirow{2}{*}{$\begin{array}{c}\text { Masa Kerja } \\
\text { (Tahun) }\end{array}$} & \multicolumn{6}{c}{ Kelelahan } \\
\cline { 2 - 7 } & \multicolumn{2}{c}{ Rendah } & \multicolumn{2}{c}{ Sedang } & \multicolumn{2}{c}{ Tinggi } \\
\cline { 2 - 7 } & $\mathbf{n}$ & $\mathbf{( \% )}$ & $\mathbf{n}$ & $\mathbf{( \% )}$ & $\mathbf{n}$ & $\mathbf{( \% )}$ \\
\hline$<5$ & 0 & 0 & 6 & 25,0 & 0 & 0 \\
$6-10$ & 0 & 0 & 1 & 4,2 & 1 & 4,2 \\
$>10$ & 3 & 12,5 & 9 & 37,5 & 4 & 16,7 \\
\hline
\end{tabular}

Tabulasi Silang Masa Kerja dan Kelelahan Kerja Subjektif

Hasil pada Tabel 7 menunjukkan bahwa responden dengan masa kerja di bawah sama dengan 5 tahun semuanya mengalami kelelahan sedang. Responden dengan masa kerja 6-10 tahun sama-sama mengalami kelelahan sedang dan tinggi sebesar 4,2\%. Responden dengan masa kerja lebih dari 10 tahun mayoritas memiliki kelelahan sedang sebesar $37,5 \%$.
Tabel 8. Tabulasi Silang Status Gizi dan Kelelahan Kerja Subjektif di PT. XYZ Tahun 2017

\begin{tabular}{lllcccr}
\hline \multirow{2}{*}{ Status Gizi } & \multicolumn{5}{c}{ Kelelahan } \\
\cline { 2 - 7 } & \multicolumn{2}{c}{ Rendah } & \multicolumn{2}{c}{ Sedang } & \multicolumn{2}{c}{ Tinggi } \\
\cline { 2 - 7 } & $\mathbf{n}$ & $\mathbf{( \% )}$ & $\mathbf{n}$ & $\mathbf{( \% )}$ & $\mathbf{n}$ & $\mathbf{( \% )}$ \\
\hline Kurang & 0 & 0 & 0 & 0 & 1 & 4,2 \\
Normal & 2 & 8,3 & 1 & 41,7 & 1 & 4,2 \\
Lebih & 1 & 4,2 & 6 & 25,0 & 3 & 12,5 \\
\hline
\end{tabular}

\section{Tabulasi Silang Status Gizi dan Kelelahan}

Tabel 8 merupakan hasil tabulasi silang dari variabel status gizi dengan kelelahan pada responden dalam penelitian. Hasil pada Tabel 8 dapat diketahui bahwa responden yang memiliki gizi normal cenderung lebih banyak merasakan kelelahan tingkat sedang sebesar $41,7 \%$.

\section{Tabulasi Silang Kebisingan dan Kelelahan Kerja Subjektif}

Hasil tabulasi silang antara variabel kebisingan dengan kelelahan kerja subjektif pada Tabel 9 menunjukkan hasil bahwa responden yang bekerja pada lingkungan dengan intensitas kebisingan melebihi NAB mengalami kelelahan kerja sedang dan tinggi dengan masing-masing sebanyak 13 responden atau sebesar $54,2 \%$, dan sebanyak 4 responden atau sebesar $16,7 \%$. Responden yang bekerja pada lingkungan dengan intensitas kebisingan sesuai NAB cenderung mengalami kelelahan kerja rendah dan sedang dengan masing-masing sebanyak 3 responden atau 12,5\%.

Tabel 9. Tabulasi Silang Kebisingan dan Kelelahan Kerja Subjektif di PT. XYZ Tahun 2017

\begin{tabular}{lcccccr}
\hline \multirow{2}{*}{ Kebisingan } & \multicolumn{5}{c}{ Kelelahan } \\
\cline { 2 - 7 } & \multicolumn{2}{c}{ Rendah } & \multicolumn{2}{c}{ Sedang } & \multicolumn{2}{c}{ Tinggi } \\
\cline { 2 - 7 } & $\mathbf{n}$ & $\mathbf{( \% )}$ & $\mathbf{n}$ & $\mathbf{( \% )}$ & $\mathbf{n}$ & $\mathbf{( \% )}$ \\
\hline Sesuai NAB & 3 & 12,5 & 3 & 12,5 & 1 & 4,2 \\
Melebihi NAB & 0 & 0 & 13 & 54,2 & 4 & 16,7 \\
\hline
\end{tabular}

\section{PEMBAHASAN}

\section{Umur}

Hasil penelitian menunjukkan responden terbanyak berada pada kelompok usia di atas 40 tahun yaitu sebesar 50\% dan mengalami kelelahan 
yang bervariasi. Hal tersebut terjadi karena pada umur yang lebih tua terjadi penurunan kekuatan otot (Eraliesa, 2008). Menurut Tarwaka dkk. (2004) kemampuan fisik yang dimiliki seseorang paling optimal berada pada usia $25-30$ tahun, setelah itu terjadi penurunan kapasitas fisik $1 \%$ setiap tahunnya.

\section{Masa Kerja}

Masa kerja dalam penelitian dikategorikan menjadi 3 kelompok yaitu masa kerja kurang dari sama dengan 5 tahun, masa kerja 6 sampai dengan 10 tahun, dan masa kerja di atas 10 tahun. Penelitian melibatkan 24 responden didapatkan mayoritas responden memiliki masa kerja di atas 10 tahun sebesar 16 responden atau $66,7 \%$. Hal ini menunjukkan bahwa para responden merasa betah dan nyaman bekerja di PT. XYZ Sidoarjo dilihat dari lamanya mereka bekerja. Masa kerja disini maksudnya adalah lama tahun responden bekerja semenjak masuk perusahaan sampai sekarang.

Masa kerja dapat memengaruhi pekerjaan seseorang. Seseorang yang bekerja dengan masa kerja yang cukup lama diperkirakan seseorang tersebut akan memiliki pengalaman lebih dalam bekerja dan diharapkan mampu beradaptasi dengan lingkungan tempat mereka bekerja dan dengan pekerjaannya, hal ini seusai dengan pernyataan dari Suma'mur (2009). Tubuh manusia akan semakin efisien dalam melakukan pekerjaan dengan meningkatkan keterampilan kerja. Hal ini dimaksudkan untuk mengurangi beban kerja dan kelelahan yang timbul akibat kerja.

Masa kerja juga dapat memberikan pengaruh negatif yaitu semakin lama bekerja dapat menimbulkan kelelahan dan kebosanan. Semakin lama bekerja, tekanan yang didapatkan pekerja pada proses kerja dapat menimbulkan kelelahan yang akan menyebabkan batas ketahanan tubuh menjadi lebih. Tekanan fisik akan terakumulasi setiap hari pada suatu masa yang panjang mengakibatkan berkurangnya kinerja otot dan menyebabkan makin rendahnya gerakan.

\section{Kebisingan}

Sumber kebisingan di area produksi PT. XYZ Sidoarjo berasal dari beberapa faktor, salah satunya yang paling mendominasi adalah dari suara mesin produksi yang beroperasi atau berasal dari suara yang dihasilkan oleh aktivitas kerja pekerja itu sendiri, suara angin, dan suara forklift. Kebisingan yang dialami pekerja merupakan kebisingan kontinyu yang artinya kebisingan berlangsung terusmenerus yang dihasilkan dari suara mesin produksi yang selalu aktif.

Hasil perhitungan kebisingan yang dilakukan di area produksi didapatkan bahwa intensitas kebisingan tertinggi berada pada bagian hammer mill fine grinding yaitu sebesar 100,7 dBA dan terendah berada pada operator boiler batu bara yaitu sebesar 64,7 dBA. Sebagian besar area kerja pekerja operator memiliki intensitas kebisingan di atas NAB sebesar $(70,8 \%)$. Sebagian besar responden bekerja dengan di lingkungan kerja dengan intensitas kebisingan melebihi NAB yang telah ditetapkan pada Peraturan Menteri Tenaga Kerja dan Transmigrasi Nomor PER.13/MEN/X/2011 Tahun 2011 tentang Nilai Ambang Batas Faktor Fisika di Tempat Kerja yaitu sebesar 85 dBA selama waktu kerja 8 jam per hari.

\section{Kelelahan Kerja Subjektif}

Pengukuran kelelahan dalam penelitian ini menggunakan pengukuran perasaan kelelahan secara objektif yang diukur menggunakan kuesioner dari Industrial Fatigue Research Committee (IFRC). Kuesioner ini berisi 30 pertanyaan yang terdiri dari 10 pertanyaan tentang pelemahan kegiatan, 10 pertanyaan tentang pelemahan motivasi, dan 10 pertanyaan tentang gambaran kelelahan fisik. Hasil skor dari pertanyaan tersebut nantinya akan dikategorikan menjadi 4 (empat) kategori, yaitu kelelahan rendah, kelelahan sedang, kelelahan tinggi, dan kelelahan sangat tinggi.

Hasil penelitian menunjukkan sebagian besar responden memiliki kelelahan sedang sebesar $66,7 \%$. Sebesar $12,5 \%$ responden memiliki kelelahan tingkat rendah dan 20,8\% lainnya memiliki kelelahan tingkat tinggi. Tidak ada satu pun responden yang mengalami kelelahan kerja sangat tinggi. Hal ini disebabkan responden bekerja sesuai jam yang sudah ditetapkan perusahaan yaitu selama $8 \mathrm{jam} / \mathrm{hari}$ dengan istirahat selama $1 \mathrm{jam}$, telah sesuai dengan Undang-Undang Nomor 13 Tahun 2003 tentang Ketenagakerjaan.

Kelelahan yang terjadi dapat disebabkan karena pekerjaan yang monoton dimana tidak ada tantangan bagi pekerja selama bekerja. Pekerja operator mesin memiliki jobdesk yang hampir sama setiap harinya. Hal ini sejalan dengan pendapat Suma'mur (2009) bahwa keadaan monoton dalam bekerja dapat menjadi salah satu penyebab kelelahan kerja. Kelelahan pekerja dapat disebabkan oleh lingkungan kerja area produksi cukup panas dan bising menjadi 
beban tambahan yang dirasakan oleh pekerja. Hal ini juga dapat menyebabkan perasaan keluhan kelelahan kerja meningkat.

Suma'mur (2009) menyatakan bahwa, hampir setiap hari setiap unit kerja selalu mengeluhkan kelelahan, namun lelah itu sendiri bersifat subjektif atau dengan kata lain memiliki arti yang berbeda bagi setiap orang. Kelelahan subjektif akan menyebabkan timbulnya beberapa efek kepada pekerja seperti semangat kerja menurun, prestasi kerja menurun, fungsi dan fisiologis motorik. Kelelahan kerja cenderung meningkatkan terjadinya kecelakaan kerja, sehingga hal ini dapat merugikan tenaga kerja dan perusahaan. Menurut Tarwaka, dkk (2004) kelelahan ringan pada klasifikasi kelelahan kerja bisa dianggap sebagai keadaan normal atau tidak lelah, karena dalam klasifikasi kelelahan ringan belum diperlukan adanya tindakan perbaikan karena hanya bersifat sementara dan dapat pulih kembali setelah diberikan istirahat dan energi secukupnya. Untuk kelelahan tinggi, diperlukan waktu yang lama untuk mengadakan pemulihan kembali dan ada kalanya bahkan diperlukan obat-obatan untuk memulihkan kondisi agar dapat fit kembali.

\section{Gambaran Umur dengan Kelelahan Kerja Subjektif}

Hasil penelitian menunjukkan bahwa mayoritas umur responden dengan tingkat kelelahan sedang berada pada kategori umur lebih dari 40 tahun. Pada kategori umur 18-30 tahun terdapat responden yang mengalami kelelahan tinggi, hal ini menunjukkan bahwa semakin tua umur seseorang tidak memengaruhi dengan tingkat kelelahan seseorang. Umur tidak mempunyai hubungan dengan terjadinya kelelahan kerja.

Hasil penelitian menunjukkan pada umur di atas 40 tahun didapatkan kelelahan kerja yang bervariasi. Hal ini dikarenakan semakin bertambahnya umur tubuh akan mengalami penurunan kapasitas fungsi tertentu yang dibutuhkan pekerja. Semakin bertambahnya umur maka intake oksigen akan menurun sehingga oksigen yang dibutuhkan untuk menghasilkan energi menjadi berkurang, hal itu dapat memicu timbulnya kelelahan kerja (Tarwaka, dkk 2004).

Terjadinya kelelahan tinggi di kategori umur 18-30 tahun bisa dikarenakan perasaan lelah lebih bersifat umum dan mudah dirasakan oleh siapa saja termasuk usia muda karena ini menyangkut fisik sehat atau tidaknya seseorang, sistem kerja yang diterapkan serta durasi istirahat yang dibutuhkan itu berbeda-beda.

\section{Gambaran Masa Kerja dengan Kelelahan Kerja Subjektif}

Hasil penelitian didapatkan bahwa sebagian besar responden mengalami kelelahan sedang di kategori masa kerja di atas 10 tahun sebesar 37,5\%. Hasil penelitian ini menunjukkan bahwa semakin lama masa kerja seseorang maka semakin merasa mudah lelah. Hal ini bertentangan dengan teori dari Suma'mur (2009) yang mengatakan pekerja akan dapat beradaptasi dengan lingkungan kerja ketika pekerja memiliki masa kerja yang lama. Hal ini dapat terjadi karena semakin lama bekerja maka keterampilan kerja akan meningkat dan membuat tubuh manusia menjadi efisien ketika melakukan pekerjaannya sehingga beban kerja akan berkurang dan kelelahan akan berkurang. Hal ini juga bertentangan dengan pendapat Kreitner dan Kinicki (2003) yang menyatakan bahwa pekerja yang memiliki masa kerja yang lama akan cenderung merasa betah dalam suatu organisasi dan pekerja sudah beradaptasi dengan lingkungannya sehinga pekerja akan merasa nyaman dengan pekerjaannya.

Penelitian ini sejalan dengan penelitian yang dilakukan Muizzudin (2013), yang mengatakan bahwa masa kerja berpengaruh terhadap kelelahan kerja. Tenaga kerja dengan masa kerja lebih dari 5 tahun banyak yang mengalami kelelahan dibanding dengan tenaga kerja dengan masa kerja kurang dari 1 tahun. Hal ini dikarenakan pekerjaan monoton menyebabkan pembebanan otot secara statis yang menyebabkan nyeri otot tulang, tendon, dan sebagainya. Kelelahan kerja juga bisa disebabkan karena perasaan bosan yang dialami pekerja sehingga mengakibatkan pekerja sudah merasa lelah jauh sebelum memulai pekerjaan.

\section{Gambaran Status Gizi dengan Kelelahan Kerja Subjektif}

Hasil penelitian menyatakan bahwa responden paling banyak berstatus gizi normal. Dari 24 responden didapatkan sebagian besar responden memiliki status gizi normal mengalami kelelahan kerja sedang dan sebanyak 1 responden dengan status gizi kurang mengalami kelelahan kerja tinggi. Hal ini dapat dikatakan status gizi tidak mempunyai hubungan dengan terjadinya kelelahan kerja. Hal tersebut disebabkan sebagian besar responden yang mempunyai status gizi normal juga mengalami 
kelelahan kerja sedang, yang artinya status gizi seseorang tidak menjadi penyebab dari terjadinya kelelahan kerja seseorang.

Suma'mur (2009) mengungkapkan bahwa seseorang dengan status gizi kurang cenderung mengubah cadangan gizi untuk menjadi energi saat beraktivitas. Masalah perbaikan dan peningkatan gizi merupakan hal yang sangat penting dalam usaha menyehatkan dan meningkatkan produktivitas kerja.

Supriasa, dkk (2013) menyebutkan bahwa masalah gizi seperti kekurangan dan kelebihan pada orang dewasa (usia 18 tahun ke atas) merupakan masalah penting yang harus diperhatikan. Hal ini dikarenakan selain mempunyai risiko terhadap penyakit tertentu juga menyebabkan pekerja cepat mengalami kelelahan dan akan memengaruhi produktivitas.

Terdapat penelitian yang menyatakan bahwa tidak ada hubungan antara status gizi dengan kelelahan kerja, yaitu pada penelitian yang dilakukan Ramayanti (2015) yang menunjukkan bahwa tidak ada hubungan antara status gizi dengan kelelahan kerja. Penelitian yang dilakukan oleh Verawati (2016) mengenai hubungan tingkat kelelahan subjektif dengan produktivitas pada tenaga kerja menunjukkan bahwa variabel status gizi dengan kelelahan subjektif memiliki tingkat hubungan lemah. Hal ini menunjukkan bahwa tidak ada hubungan antara status gizi dengan kelelahan subjektif.

\section{Gambaran Kebisingan dengan Kelelahan Kerja Subjektif}

Hasil pengukuran intensitas kebisingan yang dilakukan oleh peneliti menunjukkan angka kebisingan yang tinggi pada sebagian besar area kerja. Intensitas kebisingan tersebut melebihi NAB kebisingan yang ditetapkan Peraturan Menteri Tenaga Kerja dan Transmigrasi Nomor PER.13/ MEN/X2011 tentang Nilai Ambang Batas Faktor Fisika dan Faktor Kimia di Tempat Kerja yaitu sebesar $85 \mathrm{~dB}$ selama 8 jam per hari atau 40 jam per minggu.

Hasil penelitian menyatakan Kelelahan kerja rendah pada intensitas kebisingan kurang dari NAB sebesar $12,5 \%$. Kelelahan kerja sedang pada intensitas kebisingan kurang dari NAB sebesar $12,5 \%$ dan pada intensitas melebihi NAB sebesar
$54,2 \%$ maka kelelahan sedang banyak dialami oleh responden yang bekerja di area yang intensitas kebisingannya melebihi NAB. Kelelahan kerja tinggi pada intensitas kebisingan kurang dari NAB sebesar $4,2 \%$ dan pada intensitas melebihi NAB sebesar $16,7 \%$. Kelelahan rendah dan tinggi banyak dialami oleh responden yang bekerja di area intensitas kebisingan melebihi NAB. Hal ini menunjukkan responden yang bekerja di lingkungan kerja dengan intensitas kebisingan melebihi NAB cenderung mengalami kelelahan dibandingkan yang bekerja di lingkungan kerja dengan intensitas kebisingan sesuai NAB.

Tempat kerja dengan intensitas kebisingan tinggi dapat menimbulkan perasaan tidak nyaman pada pekerja sehingga berpotensi menimbulkan kelelahan pada pekerja. Kebisingan memang bukan menjadi satu-satunya penyebab terjadinya kelelahan. Kebisingan dapat menjadi beban tambahan bagi pekerja yang dapat memengaruhi tingkat kelelahan yang dialami pekerja. Tarwaka (2011) menyatakan bahwa stress yang disebabkan karena pemaparan kebisingan dapat menyebabkan terjadinya kelelahan dini, kegelisahan dan depresi. Penggunaan alat pelindung diri (APD) seperti earplug atau earmuff dibutuhkan untuk mengurangi pemaparan kebisingan di area kerja.

\section{SIMPULAN}

Hasil penelitian yang dilakukan, diperoleh kesimpulan bahwa sebagian besar responden berumur di atas 40 tahun, memiliki masa kerja di atas 10 tahun, memiliki status gizi normal, bekerja di area kerja melebihi NAB dan memiliki kelelahan tingkat sedang. Mayoritas umur responden dengan tingkat kelelahan sedang berada pada kategori umur lebih dari 40 tahun. Sebagian besar responden mengalami kelelahan sedang di kategori masa kerja di atas 10 tahun (37,5\%). Responden dengan gizi normal cenderung lebih banyak merasakan kelelahan sedang sebesar (76,9\%). Sebagian besar responden bekerja di area dengan intensitas kebisingan melebihi NAB mengalami kelelahan sedang sebesar (54,2\%). Perusahaan diharapkan agar melakukan pendisiplinan tentang penggunaan APD yaitu earplug dan earmuff untuk pekerja yang berada di area dengan intensitas kebisingan melebihi NAB dan menyediakan tempat istirahat yang nyaman 
dan bebas dari bising untuk menetralkan kondisi pekerja yang telah bekerja di area dengan kebisingan melebihi NAB.

\section{DAFTAR PUSTAKA}

Badan Penyelenggara Jaminan Sosial Ketenagakerjaan., 2016. Jumlah Kecelakaan Kerja di Indonesia Masih Tinggi. Tersedia di http:// www.bpjsketenagakerjaan.go.id/berita/5769/ Jumlah-kecelakaan-kerja-di-Indonesiamasihtinggi.html. [Sitasi 16 April 2017]

Budiono, A.M., 2003. Bunga Rampai Hiperkes dan Keselamatan Kerja: Hygiene Perusahaan, Ergonomi, Kesehatan Kerja, dan Keselamatan Kerja. Semarang: Badan Penerbit Universitas Diponegoro.

Eraliesa, F. ,2008. Hubungan Faktor Individu dengan Kelelahan Kerja pada Tenaga Kerja Bongkar Muat di Pelabuhan Tapaktuan Kecamatan Tapaktuan Kabupaten Aceh Selatan 2008. Skripsi. Medan: Universitas Sumatra Utara.

Hayati, F.N., 2012. Hubungan Tingkat Kebisingan dengan Kelelahan Kerja pada Pekerja Bagian Ringframe PT. Kusumaputra Santosa Karanganyar. Skripsi. Surakarta: Universitas Sebelas Maret.

Herliani, F., 2012. Hubungan status gizi dengan Kelelahan Kerja pada Pekerja Industri Pembuatan Gamelan di Daerah Wirun Sukoharjo. Skripsi. Surakarta: Universitas Sebelas Maret.

Kreitner, R., Kinicki, A., 2003. Perilaku Organisasi. Jakarta: PT Salemba Emban Patria.

Peraturan Menteri Tenaga Kerja dan Transmigrasi Nomor PER.13/MEN/X/2011 Tahun 2011 Tentang Nilai Ambang Batas Faktor Fisika dan Faktor Kimia di Tempat Kerja. Jakarta: Kementrian Tenaga Kerja dan Transmigrasi.

Muizzudin, A., 2013. Hubungan Kelelahan Dengan Produktifitas Kerja pada Pekerja Tenun di PT. Alkatex Tegal. Jurnal Kesehatan Masyarakat. Vol. 2 No. 4.

Oentoro, S., 2004. Kampanye Atasi Kelelahan Mental dan Fisik. Jakarta: UI Press.
Purwindasari, H., 2013. Faktor yang Berhubungan dengan Kelelahan Kerja pada Tenaga Kerja Bagian Packing di PT. Charoen Pokphand Indonesia Krian. Skripsi. Surabaya: Fakultas Kesehatan Masyarakat Universitas Airlangga.

Ramayanti, R., 2015. Analisis Hubungan Status Gizi dan Iklim Kerja dengan Kelelahan Kerja di Catering Hikmah Food Surabaya. The Indonesian Journal of Occupational Safety and Health, Vol. 4, No. 2.

Sasongko, D.P,A., et al., 2000. Kebisingan Lingkungan. Semarang: Badan Penerbit Universitas Diponegoro.

Setyawati, L., 2010. Selintas tentang Kelelahan Kerja. Yogyakarta: Amara Books.

Suma'mur P.K., 2009. Higiene Perusahaan dan Kesehatan Kerja. Jakarta: Sagung Seto.

Supariasa, I.D.N., 2002. Penilaian Status Gizi. Jakarta: Penerbit Buku Kedokteran EGC.

Tarwaka, et al., 2004. Ergonomi untuk Keselamatan, Kesehatan Kerja, dan Produktivitas. Surakarta: Uniba Press.

Tarwaka., 2010. Ergonomi Industri. Surakarta: Harapan Press.

Tarwaka., 2011. Ergonomi Industri Dasar-Dasar Pengetahuan Ergonomi dan Aplikasi di Tempat Kerja. Surakarta: Harapan Press.

Tasmi, D., et al., 2015. Hubungan Status Gizi dan Asupan Energi dengan Kelelahan Kerja pada Pekerja di PT. Perkebunan Nusantara I Pabrik Kelapa Sawit Pulau Tiga Tahun 2015. Jurnal Lingkungan dan Kesehatan Kerja. Vol. 4, No. 2.

Triyunita, N., et al., 2013. Hubungan Beban Kerja Fisik, Kebisingan dan Faktor Individu dengan Kelelahan Pekerja Bagian Weaving PT. X Batang, Jurnal Kesehatan Masyarakat, Vol. 2, No. 2.

Undang-Undang Republik Indonesia Nomor 13 Tahun 2003 Tentang Ketenagakerjaan. Jakarta: Kementerian Tenaga Kerja.

Verawati, L., 2016. Hubungan Tingkat Kelelahan Subjektif dengan Produktivitas pada Tenaga Kerja Bagian Pengemasan di CV Sumber Barokah. The Indonesian Journal of Occupational Safety and Health, Vol. 5, No. 1: pp. 51-60. 